\title{
A HYPERGAME ANALYSIS OF THE BATTLE OF MAGERSFONTEIN
}

\author{
G. GELDENHUYS \\ Department of Applied Mathematics, University of Stellenbosch \\ Stellenbosch, 7600 South Africa
}

\begin{abstract}
ARSTRACT
The battle of Magersfontein, 11 December 1899, can be modelled as a hypergame. The analysis shows how British misconceptions of the Boer strategies and strength led to an ill-advised British attack with disastrous results for them. Several points in connection with hypergames are illustrated in this case study.
\end{abstract}

\section{INTRODUCTION}

P.G. Bennett and M.R. Dando's case study of the fall of France in the Sccond World War $[1]$ is at landmark in the development of the theory and applications of hypergames. One of the points made in their study is that a major cause of the Alties' defeat lay in an overly simplistic vicw of the problem in which they assumed that the enemy perceived the military situation the samc way as they did themselves. On the other hand the more imaginative of the German commanders were aware of the differences between the two sides' perceptions and put this awarencss to devastating use.

The battle of Magersfontcin, 11 December 1899, provides another example of such a situation. This battle in the Boer War is interesting cnougl in itself to warrant its own casc study. In comparison with Bennelt and Dando's study it also brings out the point more clearly that the preference orderings of the possible outcomes may vary considerably when cvaluated from differcm viewpoints. Nevertheless the techniques used are the same as in Bennett and Dando's case study. 


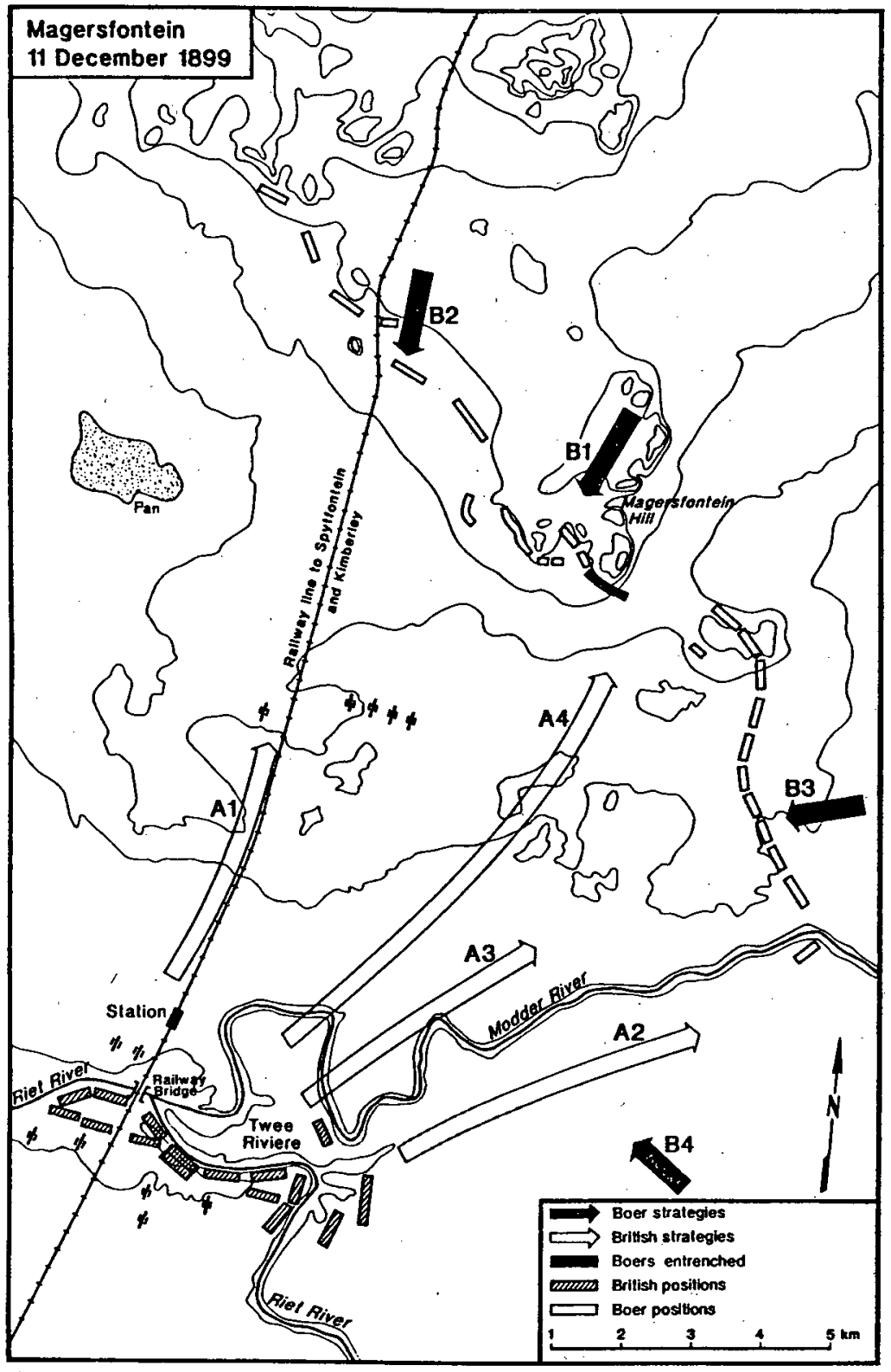

Figure 1 : Possible strategies in the battle of Magersfontein 


\section{ANALYSIS}

Early in December 1899 the British troops, in their advance on Kimberley, had crossed the railway line just north of the Modder River. The Boer forces were deployed in a line from north to cast on both sides of the nearby Magersfontein Hill. Magersfontein Hill rises abruptly from the vcld and, although only $55 \mathrm{~m}$ above the surrounding ground, dominates the countryside for many kiloncters in all directions.

On the eve of the battle the British commander, Lord Methuen, formulated his military options in terms of the following possible stratcgies

A1 : Attack along the railway line to Kimberley:

A2: Executc a flank march to the east to Abon's Dam and thence atlack Spytfontein, north of Magers[ontein Hill

A3 : $\quad$ Assault the left flank of the Boers

A4 : Storm Magersfontein Hill and capture the Boer positions in a short, sharp bayonct atlack

A fifth option, to pass further west of Magersfontcin and attack Spyfontein, was discarded because the country was so waterless as to preclude any attempt in that dircction.

The British perception of the Boer strategies was as follows :

B1 : Altack from the top of Magersfontein Hill

B2: Concentrate defence on the railway line

B3 : Counterattack by the Boer left wing

B4: Attack Modder River camp with a small force from the south

The strategies as discussed above are also shown on the map in Figure 1.

With this background the preference matrix as seen by the British could be as in Figure 2 .

\begin{tabular}{|c|c|c|c|c|c|c|}
\hline & & & & Conc & $\begin{array}{l}\text { ners } \\
\text { ntrate on }\end{array}$ & \\
\hline & & & $\begin{array}{c}\text { Hill } \\
\text { B1 }\end{array}$ & $\begin{array}{c}\text { Railway } \\
\text { B2 }\end{array}$ & $\begin{array}{c}\text { Left flank } \\
\text { B3 }\end{array}$ & $\begin{array}{c}\text { South } \\
\text { B4 } \\
\end{array}$ \\
\hline & Railway & A1 & $2 ; 15$ & $6 ; 11$ & $10 ; 7$ & $14 ; 3$ \\
\hline & March cast & A2 & $9 ; 8$ & $5 ; 12$ & $7 ; 10$ & $1 ; 16$ \\
\hline British & Altack left flank & A3 & $4 ; 13$ & $8 ; 9$ & $3 ; 14$ & $12 ; 5$ \\
\hline & Altack hill & A4 & $15 ; 2$ & $11 ; 6$ & $13 ; 4$ & $16 ; 1$ \\
\hline
\end{tabular}

Figure 2 : British perception of the military situation 
There are 16 strategy pairs of the form ( $A \mathrm{i} ; \mathrm{Bj})$. An entry such as (ai; bj) in the matrix denotes that from the British viewpoint the outcome for the strategy pair ( $\mathrm{Ai}$; $\mathrm{Bj}$ ) has a preference ordering of ai for the British and bj for the Bocrs. The highest ordering is 16 and the lowest 1 . For convenience it is assumed that the British ordering from the British viewpoint is the opposite of that of the Boers' ordering from the British vicwpoint.

The choice of preference orderings is subjeclive but hopefully not illogical. It is based on historical analyscs (for example Breytenbach [2], Duxbury [4], Maurice [5] and Pakenham [6]) and eyewitness accounts (for example Totius [8] and those mentioned in Davitt [3] and Spies [7]). For examplc, the British ranking of the entries in the row for A4 in Figure 2 can be motivated as follows. The capture of Magersfontein Hill was very inportant from the British viewpoint. It was their intention to march on the Hill during the night and execute a surprise attack at first light. Rumour had it that the Boers fcarcd and despised the bayonet because they regarded it as a barbaric weapon (Duxbury [4]). The British evaluation of the Bocr psychology and positions explains their optimistic vicw of the possiblitics in row A4 and in particular of the outcome when the Boers concentrate their defence on Magersfontein Hill. If the Boers were really concentrating on the south the victory would be even casicr and the resulting tactical situation even belter for the British. From the geographical positions indicatcd in Figure 1 it is clear that more resistance could be expected if the Boers were concenlrating on their own left flank, but that this would be less if they were in fact concentrating on the railway line.

The game matrix has a unique stable solution for the stratcgy pair (A4; B2) in the sense that neither of the two sides would obtain a better ordering if it should decide unilaterally to change its strategy. For example, if the British arc committed to A4 but the Boers change their strategy, nonc of the other preference orderings of 2, 4 or 1 are better than the preference ordering of 6 for them for the stratcgy pair $(\mathrm{A} 4 ; \mathrm{B} 2)$. Similarly, if the Boers are committed to $\mathrm{B} 2$ but the British change their strategy, none of the other preference orderings of 6,5 or 8 are better than the preference ordering of 11 for them for the stable solution. The stable solution indicates that the British forces should altack Magersfontcin Hill and that the Boers should concentrate their defence on the railway line.

This British viewpoint was defeclive on various counts. In the first place their estimate of the strength of the Bocr forces was approximalely $50 \%$ too high. In the sceond place they did not notice scveral weak spots on Boer left flank. Their biggest mistake was that they missed an important Boer strategy, namely the use of trenches. At the insistence of General Koos de la Rey they had prepared a number of trenches, the most important of which were those just south of Magersfontcin Hill. Because of a number of reasons the presence of these trenches was not discovered by the British before the battle.

Because of the three factors mentioned above the Bocrs' perception of the military situation differed from those of the British. In terms of a hypcrgame analysis this can be modelled in two ways. In the 
first place the modeller can use different preference orderings for the Boers' perception of the outcomes of the various strategy pairs. In the second place the Boers' game matrix can be cxpanded to include a strategy (not shown explicitly in Figure 1) which does not occur in the British game matrix, namcly :

B5: Concentrate defence on the trenches at the foot of Magersfontcin Hill

A plausible game matrix according to the Boers' perception is given in Figure 3. The strategy pair (A3; B5) in the new game matrix is a stable solution which provides a fairly satisfactory military outcome for the Boer forces. On the other hand the Boers had devised their stratcgy B5 preciscly because of its element of surprise. When the British launched a great military barrage on the ridge of Magersfontein Hill on 10 December the Boers had every reason to belicve that their trenches had not been detected and that they could therefore exploit this information in their planning.

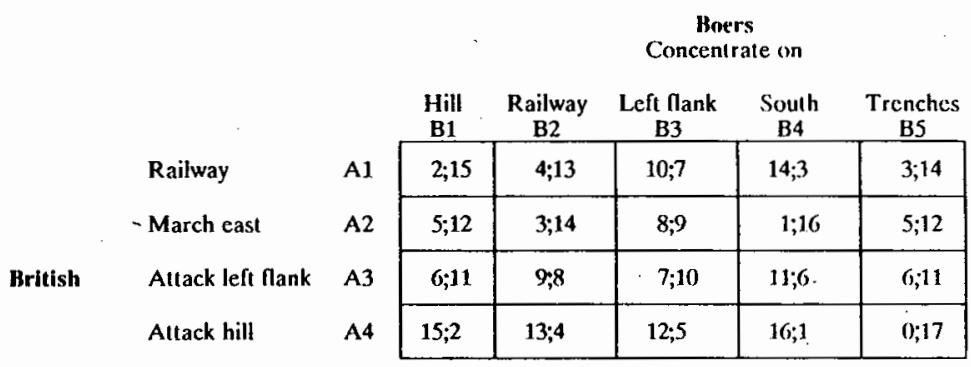

Figure 3 : Boer perception of the military situation

The model in Figure 3 has the capacity to illustrate these aspects. If the column for B5 is removed from consideration the remaining game matrix has a stable solution for the strategy pair (A4; B3), which from the Boer viewpoint is not as advantageous as (A3; B5). Nevertlucless the model shows that the British will select A4 if they are not aware of B5. Therefore the Bocrs sciect B5 in the expanded matrix, and against $\mathrm{A} 4$ this yields the best possible outcome for them.

The run of events in the real bat!le was that the British indeed chose A4 and the Bocrs B5, resulting in a terrible defeat for the British. A poignant counterpoint to the basic theme of misconception and war is provided by the little-known fact that the famous Afrikaans poet and theologian, Totius (I D du Toit), who was in the Boer camp, directed his scripture reading from 2 Corinthians 5 and his sermon on the eve of the battle to the subject of reconciliation (Totius [8]). 


\section{CONCLUSION}

Hypergame analyses are useful in siluations where the conflicling parties have different perceptions of the strategies available to them and the payoffs that result from their interactions. The battle of Magersfontein illustrates these points and serves as a grim reminder of the dire consequences that can result when a participant in a conflict fails in his evaluation of his opponent.

\section{REFERENCES}

[1] P.G. BENNETT and M.R. DANDO, "Complex strategic analysis : A hypergame study of the fall of France," Jounial of the Operational Research Society, 30, 23 - 32 (1979).

[2] J.H. BREYTENBACH, Die Geskicdenis van die Tweede Vyyheidsoorlog in Suid-Afrika, 1899 - 1902, Deel II: Die Eerste Britse Offensief, Nov. Des. 1899, The Government Printer, Pretoria (1971).

[3] M. DAVITT, The Boer Fight for Freedom, Funk \& Wagnalls, New York and London (1902).

[4] G.R. DUXBURY, The Battle of Magersfontein, South African National Museum for Military History, Johannesburg (1974).

[5] F. MAURICE, History of the War in South Africa, 1899 - 1902, Volume I, Hurst and Blackett, London (1906).

[6] T. PAKENHAM, The Boer War, Jonathan Ball Publishers, Cape Town (1979).

[7] S.B. SPIES (editor), A Soldier in South Africa : The Experiences of Eustace Abadie, 1899 to 1902, The Brenthurst Press, Houghton (1989).

[8] TOTIUS (pseudonym of J.D. du Toit), Vier-en-sestig Dae te Velde : 'n Oorlogsdagboek (with notcs by V.E. d'Assonville), Tafclberg, Cape Town (1977). 